\title{
Short Communication: \\ Composition of terpenoid compounds in essential oils extracted from stems of eight Piper species and their role in taxonomic relationships
}

\author{
LAURENTIUS HARTANTO NUGROHO, ELIZABETH CINDY LEXINTA, YOSEP PRIYONO, \\ RATNA SUSANDARINI" \\ Faculty of Biology, Universitas Gadjah Mada. Jl. Teknika Selatan, Sekip Utara, Sleman 55281, Yogyakarta, Indonesia. Tel./fax. +62-274-580839, \\ "email: ratna-susandarini@ugm.ac.id
}

Manuscript received: 19 June 2020. Revision accepted: 3 July 2020.

\begin{abstract}
Nugroho LH, Lexinta EC, Priyono Y, Susandarini R. 2020. Short Communication: Composition of terpenoid compounds in essential oils extracted from stems of eight Piper species and their role in taxonomic relationships. Biodiversitas 21: 3438-3443. Piper is widely used as source of essential oils from which many bioactive compounds with medicinal properties were used in traditional medicine. The objectives of this study were to explore the chemical composition of essential oils of eight Piper species and to identify its role in determining taxonomic relationships. Chemical composition of essential oils was analyzed using GC-MS analysis on petroleum ether extracts from stems of eight Piper species, while taxonomic relationship was determined using cluster analysis and principal component analysis. Results showed that 21 terpenoid compounds were identified as constituents of the essential oils, consisted of 4 monoterpenes, 14 sesquiterpenes, and 3 diterpenes. The composition of essential oils varied between species. Cluster analysis and principal component analysis showed that differences in the composition of essential oil compounds determined the grouping of species into two clusters. Five compounds were identified as having major role in the grouping of species. These compounds were $\alpha$-selinene, $\alpha$-caryophyllene, $\beta$-caryophyllene, farnesyl acetone, and $\alpha$-amorphene. The results of this study offer opportunities for the use of Piper stems as source of essential oils. This study also confirms the interspecies variability in composition of essential oils, and at the same time supports the use of essential oils in chemotaxonomic studies.
\end{abstract}

Keywords: Chemotaxonomy, essential oils, phytochemistry, Piper, terpenoids

\section{INTRODUCTION}

Piper is a genus with high species diversity with 600 species were recorded in tropical Asian (Martínez et al. 2015) and various habits including herbs, shrubs, and climbers (Sen et al. 2019). Many Piper species have beneficial properties and have been used in traditional medicine, modern pharmacognosy, and aromatic industry (Chaveerach et al. 2006). Piper phytochemicals have even been used in wide range of applications beneficial for human life, including medicine, phytocosmetics, and agriculture. Piper as phytomedicine has been known as having cytotoxic activity against MCF-7 human breast tumor cells (Setzer et al. 2008), as antibacterial against Escherichia coli, Klebsiella pneumonia, Staphylococcus aureus (Rocha et al. 2016), and biological activities as antileishmanial and antituberculosis (Bernuci et al. 2016). The use of Piper as phytocosmetics has been reported by Almeda et al. (2015) as an anti-tyrosinase to prevent hyperpigmentation. Meanwhile, the use of Piper in agriculture has been noted as organic insecticidal against Sitophilus oryzae (Oben et al. 2015) and for controlling phytopathogenic fungus in plants (Valadares et al. 2018).

The wide range use of Piper is due to their secondary metabolites, especially the essential oils. All parts of Piper plants contain essential oils, and therefore most of phytochemical studies on Piper were done to identify potential pharmacological properties of the oils (Dyer et al. 2004). It is known that essential oils consist of natural mixture of high complexity consisted of terpenes, phenolic, alcohol, and may include oxygenated compounds (Rassem et al. 2016).

Essential oils from Piper were commonly extracted from leaves, and thus the data on the composition of Piper leaves essential oils from various species have been widely published. Nevertheless, several studies revealed that stem, roots, and inflorescence of Piper also contain essential oils (Varughese et al. 2016; Riani et al. 2017). Previous studies showed that the composition of Piper essential oils extracted from leaves was different from those extracted from stems. Salleh et al. (2012) reported that Piper porphyrophyllum essential oils extracted from leaves had 34 constituents, while oils extracted from stems had 38 constituents. Meanwhile, Riani et al. (2017) found that Piper chimonanthifolium essential oils extracted from leaves consisted of 13 monoterpenes and 16 sesquiterpenes, whereas oils extracted from stems consisted of 12 monoterpenes and 10 sesquiterpenes. These facts bring the opportunity to further explore the potential of stems as a source of essential oils containing various bioactive compounds.

Apart from their pharmacological function, essential oil is one of plant secondary metabolites widely used in chemotaxonomic studies. The application of secondary 
metabolites in chemosystematics studies is due to their chemical composition which often specific for plant taxa and thus useful for classification (Singh 2016). Chemosystematic studies based on chemical profile of the essential oils on Piper have been done by Hieu et al. (2015), by Hao et al. (2018) and de Araujo et al. (2019). In fact, majority of chemotaxonomic studies on Piper were carried out based on essential oils. Chemotaxonomic studies based on secondary metabolites, especially essential oils have been reported in various plant taxa such as those by Killic (2013) in Centaurea, by Susandarini et al. (2016) in Citrus maxima, and by Olugbade et al. (2017) in genus Ocimum. In this case, Bhargava et al. (2013) noted the importance of essential oils especially the presence of monoterpenes, sesquiterpenes, diterpenes, and triterpenes in chemosystematic studies, such as found in Piperaceae, Rutaceae, Verbenaceae, and Myrtaceae. The important role of chemotaxonomic research was mentioned by Liu et al. (2017) that classification of plants based on the diversity of chemical compounds might provide predictive value in bioprospecting for medicinal plants.

The objective of this study was to explore the essential oil composition of petroleum ether extracts from stems of Piper, and to reveal the role of these compounds in determining taxonomic relationships among eight Piper species. The chemosystematics analysis conducted in this study is expected to support the role of essential oils as taxonomic evidence. Results of this study are expected to raise the potential of Piper's stem as an alternative source of bioactive compounds with various potential uses. Information on the essential oil composition from Piper stems might be useful in uncovering their potential in the discovery of medicinal ingredients and other industries based on essential oils.

\section{MATERIALS AND METHODS}

\section{Materials}

Eight species of Piper used in this study (Table 1) were previously obtained from the living collection of the Bogor Botanical Gardens, and has been grown in the research garden at the Faculty of Biology Universitas Gadjah Mada for one year. Fresh stems used for the extraction of essential oils were collected from plants of relatively at the same age under the same growing condition. Extraction of stem essential oils was done using solvent extraction method (Rassem et al. 2016). The extract was then diluted in $0.5 \mathrm{ml}$ methanol before subjected to gas chromatography analysis.

\section{Methods}

The GC-MS analysis was performed using HP5 column (30 m x $0.25 \mathrm{~mm}$, film thickness $0.25 \mu \mathrm{m})$, with initial temperature at $100^{\circ} \mathrm{C}$ and final temperature at $280^{\circ} \mathrm{C}$. The reaction was run with initial time for 5 minutes and subsequent temperature increment of $20^{\circ} \mathrm{C} /$ minutes. The amount of samples injected was $1 \mu \mathrm{l}$. The injection temperature was at $280^{\circ} \mathrm{C}$, using helium as gas carrier, with total flow of 10 and split of 60 . The detector used in this analysis was flame ionization detector, at the temperature of $300^{\circ} \mathrm{C}$. Identification of essential oil compounds represented as peaks in chromatograms resulted from gas chromatography was based on analysis of the fragmentation patterns, by computer matching against the mass spectral library of the GC-MS data system (WILEY $10^{\text {th }}$ ), and published mass spectra (Adams 2007).

\section{Data analysis}

Following identification of each essential oils composition, each compound representing chemotaxonomic characters was converted into numerical scores for the subsequent analysis using numerical taxonomy methods. The conversion was done following the principles of numerical taxonomy, by determining classes of compound's concentration range from 0 to 50 with the interval of 5, which resulted in categorical data. The grouping of species was determined using cluster analysis with UPGMA clustering technique based on percent similarity coefficient. A principal component analysis was carried out to examine the role of essential oil compounds in the grouping of species. Cluster analysis and principal component analysis were performed using MVSP version 3.1 .

Table1. Piper species used in this study

\begin{tabular}{lll}
\hline Species name & Habit & Natural distribution \\
\hline Piper acutilimbum C. DC. & Shrub & Asia, Australia, Africa, tropical America \\
Piper baccatum Blume & Shrub & Asia \\
Piper betle L. & Climbing shrub & Asia, New Guinea, Africa \\
Piper caninum Blume & Climbing shrub & Asia, New Guinea, northern Australia, Solomon Islands \\
Piper majusculum Blume & Shrub & Asia, New Guinea \\
Piper mollissimum Blume & Shrub & Southeast Asia \\
Piper porphyrophyllum (Lindl.) N.E.Br. & Shrub & Southeast Asia \\
Piper sarmentosum Roxb. & Shrub & Southeast Asia \\
\hline
\end{tabular}




\section{RESULTS AND DISCUSSIONS}

\section{Composition of terpenoid compounds in essential oils}

The GC-MS analysis on stem essential oils revealed that the essential oils extracted from stem of eight Piper species consisted of 21 compounds (Table 2). The composition of essential oils consisted of 4 monoterpenes, 14 sesquiterpenes, and 3 diterpenes. Results of GC-MS analysis in this study showed that the number of compounds detected was different for each species. Differences in the number of essential oil compounds in each species indicated interspecies variability in the chemical profile. This finding is in agreement with previous studies on genus Piper which found interspecies differences in oils composition, such as those among $P$. majusculum, $P$. harmandii, and $P$. brevicaule in Vietnam (Hieu et al. 2015). Interspecies differences in essential oils composition within the genus Piper was also found in other studies such as those by Cruz et al. (2012) in fifteen Piper species from Guatemala, and Hao et al. (2018) in ten Piper species from South China.

Composition of essential oils compounds found in this study showed that sesquiterpene was predominating over other groups of terpenes. The dominance of sesquiterpenes in essential oils was also found in Piper cernuum, $P$. glabratum, P. hispidum, and P. madeiranum (Assis et al. 2013). The dominance occurrence of sesquiterpene compounds was reported in essential oils of Piper lanceaefolium and Piper hispidum (Benitez et al. 2009). Similarly, Bernuci et al. (2016) found that the essential oils of $P$. rivinoides, $P$. arboretum, and $P$. aduncum were dominated by sesquiterpenes. de Araujo et al. (2019) also noted the dominance of sesquiterpene compounds in the essential oils of $P$. coariense, $P$. auriculifolium, $P$. curtistilum, and $P$. brevesanum. This study also proved that petroleum ether is a suitable solvent for extracting essential oils from plant materials. The use of petroleum ether for extraction of bioactive phytocompound in medicinal plants has been reported for Ficus krishnae (Kanjikar and Londonkar 2017) and for Lepidagathis scariosa (Sharmila et al. 2019). Results of this study indicated that Piper stems could be used as an alternative material to obtain essential oils that have various bioactive ingredients. The use of Piper stems as a source of essential oil has been done in several species, including Piper porphyrohyllum (Salleh et al. 2012) and Piper kadsura (Liu et al. 2015).

The use of GC-MS in this study was successfully generated chemical profile of Piper essential oils. The vast application of GC-MS for chemical profiling is due to a combination of two analytical techniques that have the ability to reliably characterize a complex mixture of phytochemical compounds (Hussain and Maqbool 2014). It is, therefore, GC-MS has been widely used in phytochemical studies for separation and identification of various secondary metabolite compounds, including longchain hydrocarbon compounds, alcohols, acids, esters, and ether from a few grams of plant materials (Abo-Altemen et al. 2019; Sanjaya and Lekha 2019). Analysis of phytochemical content using GC-MS can provide an overview of the pharmaceutical value of plants, and thus generally applied in preliminary studies to recognize the potential of medicinal plants (Gomathi et al. 2015; Rukshana et al. 2017). Phytochemical studies using GCMS as an initial step for screening and characterization of secondary metabolites of pharmaceutics potential in Piper was carried out by Zahira et al. (2016) in Piper nigrum. In that study, a number of phytocompounds were successfully identified using GC-MS, including terpenoids, alkaloids, flavonoids, phenols, tannins, saponins, and phytosterols, and thereby confirming the use of $P$. nigrum as a medicinal plant.

\section{Taxonomic relationships of eight Piper species based on essential oils compounds}

The UPGMA clustering of eight Piper species based on composition of 21 on essential oils compounds as displayed in the dendrogram (Figure 1) showed the grouping of species into 2 clusters, marked as cluster I and cluster II. The first cluster consisted of six Piper species, while the second cluster only consisted of $P$. caninum and $P$. baccatum. This clustering pattern was mainly due to differences in the composition of essential oil compounds detected in each species. The six species belong to the first cluster, i.e., $P$. acutilimbum, $P$. sarmentosum, $P$. betle, $P$. porphyrophyllum, $P$. majusculum, and $P$. molissimum, were characterized mainly on the presence of $\alpha$-amorphene, $\alpha$ caryophyllene, $\alpha$-selinene, and $\beta$-caryophyllene. Members of this first cluster were clearly differed from two species in second cluster, P. caninum, and P. baccatum, by the absence of farnesyl acetone. The clustering pattern of Piper species was not correlated to their habit as well as their natural distribution areas. A review on Piper essential oils by da Silva et al. (2017) noted that the interspecific and intraspecific variations on essential oils composition due to differences in sites of collection and seasonality. Such a case was not found in this study since all Piper species used were grown in the same location and harvested at the same time prior to oils extraction process.

In order to determine the main sources of variability in defining the grouping pattern observed in cluster analysis, a principal component analysis (PCA) was performed. PCA is a type of multivariate analysis method commonly used in establishing relations between samples and variables, and for identifying variables which has important contribution in sample characterization and classification (Câmara et al. 2006). The loading scores resulted from PCA (Table 3) indicated that $\beta$-caryophyllene, $\alpha$-selinene, farnesyl acetone, $\alpha$-caryophyllene, and $\alpha$-amorphene showed major contribution in differentiating species into two clusters. The role of these five compounds was indicated by their absolute loading scores of $\geq 0.3$ in the first axis of PCA. Observation on the loading scores on the second axis of PCA revealed that germacrene-D was has a major role in the formation of a subcluster IA which consisted of $P$. sarmentosum and $P$. acutilimbum. These two species have notably characterized by germacrene-D, which was absent from the rest of four species within the first cluster. 
Table 2. Chemical composition of essential oils extracted from stems of eight Piper species

\begin{tabular}{|c|c|c|c|c|c|c|c|c|c|c|c|c|}
\hline \multicolumn{10}{|l|}{$r \mathrm{sp}$} & \\
\hline \multirow{2}{*}{\multicolumn{10}{|c|}{$\begin{array}{c}\text { Compound detected in Piper } \\
\text { species }\end{array}$}} & Characters & Axis 1 & Axis 2 \\
\hline & & & & & & & & & & $\alpha$-pinene & 0.060 & 0.046 \\
\hline
\end{tabular}

Table 3. PCA loadings of 21 essential oil compounds

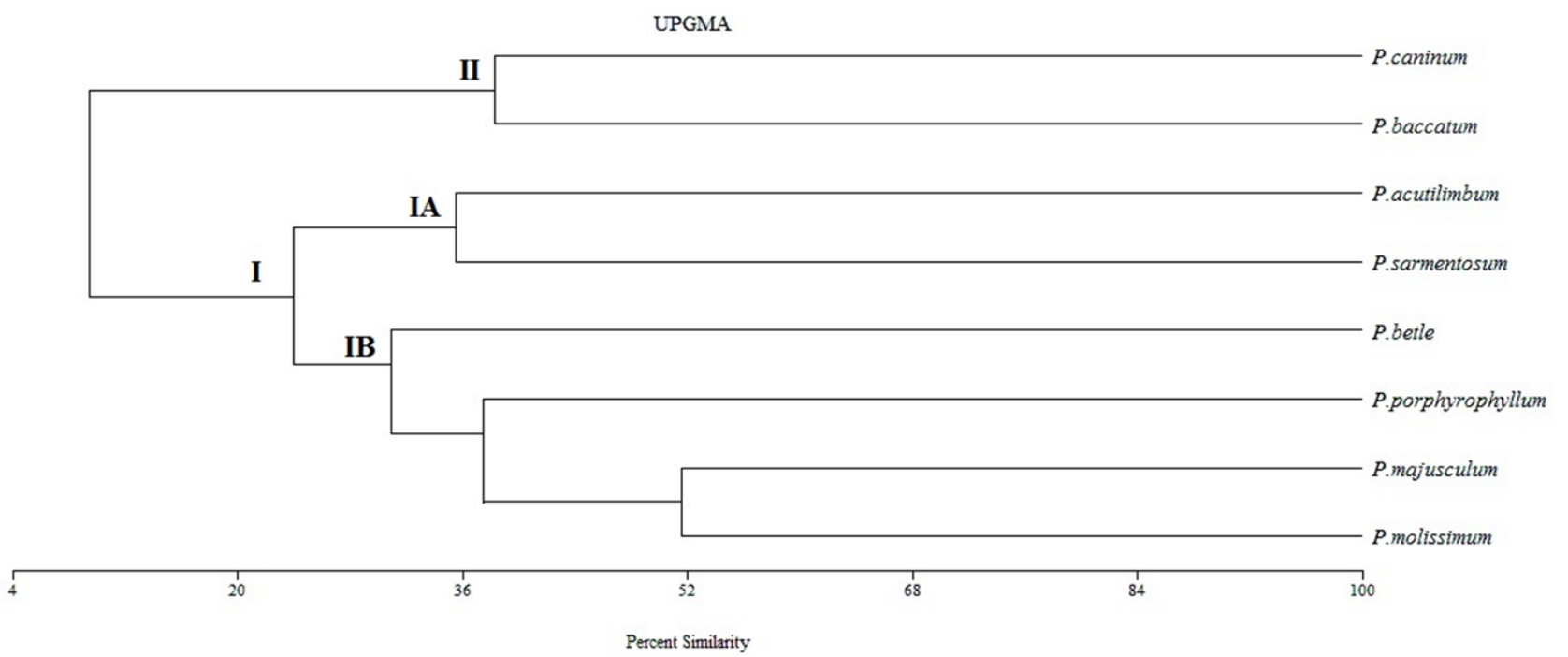

Figure 1. Dendrogram showing the grouping of eight Piper species based on composition of 21 essential oils compounds 
This result showed that PCA confirmed the grouping patterns resulted from cluster analysis, and supported the characterization of Piper species based on the composition of their essential oils. The successful application of PCA for chemical characterization of four Cecropia species has been reported by Rivera-Mondragón et al. (2019), and in identifying the most attractive cultivars of Prunus persica based on polyphenols, carotenoids, sugars, and organic acids content (Nowicka et al. 2019). The use of PCA in discerning characterization of Piper species based on composition of essential oils was mentioned by Varughese et al. (2016) and de Araujo et al. (2018) which found that differences in composition of essential oils were the determining factor in the recognition of interspecific variations. The results of these previous studies regarding interspecific variations on Piper essential oils were in agreement with the finding of this study.

The diversity of essential oils in various plant taxa has been investigated at various plant groups to explore its application in chemotaxonomic studies. The use of essential oils in chemotaxonomy has been reported in a number of studies at species and intraspecies levels, such as in Achillea millefolium (Judzentiene and Mockute 2010), in three taxa of Centaurea (Kilic 2013), and in Citrus maxima (Susandarini et al. 2016). Chemotaxonomic studies based on the content of essential oils in Juniperus microsperma even provided an indication of the evolution in this species (Adams et al. 2013). The use of phytochemical data in taxonomic studies had been accepted as one of the effective tools for the purpose of taxonomic revision and phylogenetic relationships, such as reported in genus Amomum (Setyawan 2002).

Previous studies showed the role of essential oils in Piper taxonomy. Characterization of essential oils on 12 Piper species from Costa Rica by Setzer et al. (2008) showed differences in the composition of essential oils between species. Similarly, interspecies variations in the composition of essential oils were also reported by Hao et al. (2018) on 10 Piper species from China and by de Araujo et al. (2019) on six Piper species from Brazil. These studies emphasize the role of essential oils in the chemical characterization of Piper based on the presence of dominant essential oil compounds. Variations in the composition of essential oils were found even among varieties in Piper betle, and thus useful in the identification of varieties (Karak et al. 2018).

Analysis of the terpenoid content in the essential oils extracted from stems of eight Piper species which has detected 21 terpenoid compounds provided evidence on the potential of Piper stems as source of essential oils. Differences in the composition of terpenoid compounds at the species level provided scientific basis for species utilization with specific bioactive compounds. The application of multivariate analysis were successfully identified particular compounds determining the grouping of species based on their chemical composition, and thus emphasizing the role of essential oils in chemotaxonomic research.

\section{ACKNOWLEDGEMENTS}

The authors acknowledge financial support from Faculty of Biology Universitas Gadjah Mada under the scheme of "Research Funding for Lecturer" granted to the first author in facilitating the undergraduate students' final projects. High appreciation is delivered to Bogor Botanical Garden for providing plant materials used in this study. Special gratitude is addressed to Inggit Puji Astuti dan Esti Munawaroh for their kind assistance during sample collection.

\section{REFERENCES}

Abo-Altemen R, Al-Shammari AM, Shawkat MS. 2019. GC-MS analysis and chemical composition identification of Cyperus rotundus L. from Iraq. Energy Procedia 157: 1462-1474. DOI: 10.1016/j.egypro.2018.11.311.

Adams RP, Mao K, Liu J. 2013. The volatile leaf oil of Juniperus microsperma and its taxonomy. Phytologia 95 (1): 87-93.

Adams RP. 2007. Identification of Essential Oil Components by Gas Chromatography/Quadrupole Mass Spectroscopy, 4th ed. Allured Publishing Corporation, Carol Stream, IL.

Almeda F, Astorga L, Orellana A, Sampuel L, Sierra P, Gaitán I, Cáceres A. 2015. Piper genus: source of natural products with anti-tyrosinase activity favored in phytocosmetics. Intl $\mathrm{J}$ Phytocosmetics Nat Ingredients 2 (1): 6. DOI: 10.15171/ijpni.2015.06.

Assis A, Brito V, Bittencourt M, Silva L, Oliveira F, Oliveira R. 2013. Essential oils composition of four Piper species from Brazil. J Essent Oil Res 25 (3): 203-209. DOI: 10.1080/10412905.2013.767755

Benitez NP, León, EMM, Stashenko EE. 2009. Essential oil composition from two species of Piperaceae family grown in Colombia. J Chromatogr Sci 47: 804-807.

Bernuci KZ, Iwanaga CC, Fernandez-Andrade CMM, Lorenzetti FB, Torres-Santos EC, Faiões VS, Gonçalves JE, do Amaral W, Deschamps C, Scodro RBL, Cardoso RF, Baldin VP, Cortez DAG. 2016. Evaluation of chemical composition and antileishmanial and antituberculosis activities of essential oils of Piper species. Molecules 21: 1698. DOI: 10.3390/molecules21121698.

Bhargava VV, Patel SC, Desa KS. 2013. Importance of terpenoids and essential oils in chemotaxonomic approach. Intl J Herb Med 1 (2): 1421.

Câmara JS, Alves MA, Marques JC. 2006. Multivariate analysis for the classification and differentiation of Madeira wines according to main grape varieties. Talanta 68 (5): 1512-1521. DOI: 10.1016/j.talanta.2005.08.012.

Chaveerach A, Mokkamul P, Sudmoon R, Tanee T. 2006. Ethnobotany of the genus Piper (Piperaceae) in Thailand. Ethnobot Res Appl 4: 223231.

Cruz SM, Cáceres A, Álvarez LE, Apel MA, Henriques AT. 2012. Chemical diversity of essential oils of 15 Piper species from Guatemala. Acta Hort 964: 39-46. DOI: 10.17660/ActaHortic.2012.964.4

da Silva JK, da Trindade R, Alves NS, Figueiredo PL, Maia JGS, Setzer WN. 2017. Essential oils from neotropical Piper species and their biological activities. Intl J Mol Sci 18 (12): 2571. DOI: 10.3390/ijms18122571

de Araujo CA, da Camara CAG, de Moraes MM, de Vasconcelos GJN, Pereira MRS, Zartman CE. 2018. First record of the chemical composition of essential oil of Piper bellidifolium, Piper durilignum, Piper acutilimbum and Piper consanguineum from the Brazilian Amazon forest. Acta Amazonica 48 (4) 330-337. DOI: 10.1590/18094392201800771

de Araujo CA, da Camara CAG, de Moraes MM, de Vasconcelos GJN, Pereira MR,. Zartman CE. 2019. Chemical compositions of essential oil of Piper species from Atlantic Forest of Amazonia, Brazil. Rec Nat Prod 13 (4): 324-332. DOI: 10.25135/rnp.110.18.09.904

Dyer LA, Richards J, Dodson CD. 2004. Isolation, synthesis, and evolutionary ecology of Piper amides. In: Dyer LA, Palmer ADN (eds.). Piper: A Model Genus for Studies of Phytochemistry, 
Ecology, and Evolution. Kluwer Academic/Plenum Publishers, New York.

Gomathi D, Kalaiselvi M, Ravikumar G, Devaki K, Uma C. 2015. GCMS analysis of bioactive compounds from the whole plant ethanolic extract of Evolvulus alsinoides (L.) L. J Food Sci Technol 52 (2) 1212-1217. DOI: 10.1007/s13197-013-1105-9.

Hao CY, Fan R, Qin XW, Hu LS, Tan LH, Xu F, Wu BD. 2018 Characterization of volatile compounds in ten Piper species cultivated in Hainan Island, South China. Intl J Food Prop 21 (1): 633-644. DOI: 10.1080/10942912.2018.1446147.

Hieu LD, Hoi TM, Thang TD, Ogunwande IA. 2015. Volatile constituents of three Piper species from Vietnam. Natural Prod Commun 10 (11): 1997-1998.

Hussain SZ, Maqbool K. 2014. GC-MS: Principle, technique and its application in food science. Intl J Curr Sci 13: E 116-126.

Jaramillo MA, Callejas R. 2004. Current perspectives on the classification and phylogenetics of the genus Piper L. In: Dyer LA, Palmer ADN (eds.). Piper: A Model Genus for Studies of Phytochemistry, Ecology, and Evolution. Kluwer Academic/Plenum Publishers, New York.

Judzentiene A, Mockute D. 2010. Essential oil composition of two yarrow taxonomic forms. Cent Eur J Biol 5 (3): 346-352. DOI: 10.2478/s11535-010-0011-7.

Kanjikar AP, Londonkar RL. 2017. GC-MS analysis of bioactive compounds in petroleum ether extract of Ficus krishnae. Intl Res J Pharm 8 (10): 178-181. DOI: 10.7897/2230-8407.0810204.

Karak S, Acharya J, Begum S, Mazumdar I, Kundu R, De B. 2018. Essential oil of Piper betle L. leaves: Chemical composition, antiacetylcholinesterase, anti- $\beta$-glucuronidase and cytotoxic properties. J Appl Res Med Aroma 10: 85-92.

Kilic O. 2013. Essential oil compounds of three Centaurea L. taxa from Turkey and their chemotaxonomy. J Med Plants Res 7 (19): 1344 1350. DOI: $10.5897 / J M P R 12.1233$.

Liu K, Abdullah AA, Huang M, Nishioka T, Altaf-Ul-Amin Md, Kanaya S. 2017. Novel approach to classify plants based on metabolitecontent similarity. Bio Med Res Intl 2017 (2): 1-12. DOI $10.1155 / 2017 / 5296729$.

Liu Y, Huang T, Ba WJ. 2015. Chemical composition of essential oils from Piper kadsura. Chem Nat Compd 51 (3): 583-585. DOI 10.1007/S10600-015-1354-0.

Martínez C, Carvalho MR, Madriñán S, Jaramillo CA . 2015. A late Cretaceous Piper (Piperaceae) from Colombia and diversification patterns for the genus. Am J Bot 102 (2): 273-289. DOI: 10.3732/ajb.1400427

Nowicka P, Wojdyło A, Laskowski P. 2019. Principal component analysis (PCA) of physicochemical compounds' content in different cultivars of peach fruits, including qualification and quantification of sugars and organic acids by HPLC. Eur Food Res Technol 245: 929-938. DOI: 10.1007/s00217-019-03233-z

Oben EO, McConchie R, Phan-Thien K, Ntonifor NN . 2015. Essential oil composition of different fractions of Piper guineense Schumach. et Thonn from Cameroon using gas chromatography-mass spectrometry and their insecticidal effect on Sitophilus oryzae (L.). Afr J Biotech 14 (36): 2662-2671. DOI: 10.5897/AJB2015.14785

Olugbade TA, Kolipha-Kamara MI, Elusiyan CA, Onawunmi GO, Ogundaini AO. 2017. Essential oil chemotypes of three Ocimum species found in Sierra Leone and Nigeria. Med Aromat Plants 6 (2): 284. DOI: 10.4172/2167-0412.1000284
Rassem HHA, Nour AH, Yunus RM. 2016. Techniques for extraction of essential oils from plants: A Review. Aust J Basic Appl Sci 10 (16): 117-127.

Riani LR, Macedo AL, Chedier LM, Pimenta DS. 2017. Chemical Analysis of Essential Oil and Hydrolates of Leaves, Inflorescences and Stems of Piper chimonanthifolium Kunth. Rev. Virtual Quim., 2017, 9 (4), 1560-1569.

Rivera-Mondragón A, Bijttebier S, Tuenter E, Custers D, Ortíz OO, Pieters L, Caballero-George C, Apers S, Foubert K. 2019. Phytochemical characterization and comparative studies of four Cecropia species collected in Panama using multivariate data analysis. Sci Rep 9: 1763. DOI: 10.1038/s41598-018-38334-4

Rocha DS, Silva JM da, Navarro DMAF, Camara CAG, Lira CS de, Ramos CS. 2016. Potential antimicrobial and chemical composition of essential oils from Piper caldense tissues. J Mex Chem. Soc 60 (3): 148-151.

Rukshana MS, Doss A, Kumari RPTP. 2017. Phytochemical screening and GC-MS analysis of leaf extract of Pergularia daemia (Forssk) Chiov. Asian J Plant Sci Res 7 (1): 9-15.

Salleh WMNHW, Ahmad F, Sirat MH, Yen KH. 2012. Chemical compositions and antibacterial activity of the leaf and stem oils of Piper porphyrophyllum (Lind1.) N.E. Br. EXCLI Journal 11: 399-406.

Sanjaya P, Lekha K. 2019. Preliminary phytochemical analysis, GC-MS studies and antioxidant activity of Majidea zangueberica J. Kirk leaf extracts. J Med Plants Stud 7 (2): 186-195.

Sen S, Dayanandan S, Davis T, Ganesan R, Jagadish MR, Mathew PJ, Ravikanth G. 2019. Origin and evolution of the genus Piper in Peninsular India. Mo. Phylogenet Evol 138: 102-113. DOI: 10.1016/j.ympev.2019.05.033

Setyawan AD. 2002. Chemotaxonomic studies on the genus Amomum based on chemical components of volatile oils. Jurnal Hayati 9 (3): 71-79.

Setzer WN, Park G, Agius BR, Stokes SL, Walker TM, Haber WA. 2008. Chemical compositions and biological activities of leaf essential oils of twelve species of Piper from Monteverde, Costa Rica. Nat Prod Commun 3 (8): 1367-1374.

Sharmila S, Nalli R, Ramya EK, Mownika S. 2019. GC-MS Analysis of bioactive components in petroleum ether extract of Lepidagathis scariosa (Nees.)-Acanthaceae. Intl J Pharm Sci Rev Res 54 (1): 56 63.

Singh R. 2016. Chemotaxonomy: A tool for plant classification. J Med Plants Stud 4(2): 90-93.

Susandarini R, Rugayah, Nugroho LH, Subandiyah S. 2016. Chemotaxonomy of Indonesian Citrus maxima based on leaf essential oils. Online J Biol Sci 16 (1): 26-33. DOI: 10.3844/ojbsci.2016.26.33.

Valadares ACF, Alves CCF, Alves JM, Deus IPBD, Filho JGDO, Santos TCLD, Dias HJ, Crotti AEM, Miranda MLD. 2018. Essential oils from Piper aduncum inflorescences and leaves: chemical composition and antifungal activity against Sclerotinia sclerotiorum. An Acad Bras Cienc 90 (3): 2691-2699. DOI: 10.1590/00013765201820180285

Varughese T, Unnikrishnan PK, Deepak M, Balachandran I, Shree ABR. 2016. Chemical composition of the essential oils from stem, root, fruit and leaf of Piper longum Linn. J Essent Oil Bear Plants 19 (1): 52-58. DOI: 10.1080/0972060X.2015.1119065.

Zahira A, Thamilmani K, Mohamed RR. 2016. Phytochemical screening and GC-MS profiling of Piper nigrum L. World J Pharm Res 5 (5): 798-807. 